\title{
MICROSTRUCTURAL EVOLUTION OF LASER METAL DEPOSITED 17-4 PH SS-TUNGSTEN COMPOSITE WITH VARYING VOLUME PERCENT TUNGSTEN
}

\author{
A. A. Adeyemil, E.T. Akinlabil, R. M. Mahamoodi,2* \\ ${ }^{1}$ Department of Mechanical Engineering Science, University of Johannesburg, South Africa \\ ${ }^{2}$ Department of Mechanical Engineering, University of Ilorin, Nigeria \\ *Corresponding author's e-mail address: mahamoodmr2009@gmail.com
}

\begin{abstract}
This study investigates the influence of the quantity of tungsten powder on the microstructural evolution of 17-4 PH stainless steel-tungsten composite produced using laser metal deposition process. The 17-4 PH stainless steel and tungsten powders were deposited on 316 stainless steel substrate at laser power of $2600 \mathrm{~W}$. The tungsten powder flow rate was varied between $0.5 \mathrm{rpm}$ and $2.0 \mathrm{rpm}$ while 17-4 PH stainless steel powder flow rate, the scanning speed, the gas flow rate and the laser spot size were fixed at $2.0 \mathrm{rpm}, 0.5 \mathrm{~m} / \mathrm{s}, 2.5 \mathrm{l} / \mathrm{min}$ and $2.0 \mathrm{~mm}$ respectively. Five (5) multiple tracks of 17-4 PH stainless steel and tungsten powder were deposited on 316 stainless steel of $10 \mathrm{~mm}$ thickness from different hopper at 50\% overlapping percentage to produce 17-4 PH SS-W composite. During the microstructural study, it was observed that tungsten carbide has been precipitated in-situ and evenly dispersed in the 17-4 PH SS-W composite produced. SEM and EDS analyses also revealed the presence of BCC alpha $(\alpha)$ ferrite and FCC gamma $(\delta)$ ferrite with the presence of sigma $(\sigma)$ phase precipitates.
\end{abstract}

KEYWORDS: Laser Metal Deposition, Laser power, microstructure, precipitation, hardening, stainless steel, composite, tungsten.

\section{ACKNOWLEDGEMENTS}

The authors acknowledge the financial support of the Global Excellent and Stature (GES), University of Johannesburg and The National Laser Centre, Council for Scientific and Industrial Research (CSIR) in Pretoria, South Africa for the rental pool grant.

\section{REFERENCES}

[1] Leslie W. C., The physical metallurgy of steels, New York: McGraw-Hill, Inc., 1981.

[2] Smith W. F., Structure and Properties of Engineering Alloys, 2nd ed., McGraw-Hill, Inc. New York, USA, 1993, pp. 328-335.

[3] Rack H. J., Kalish D., The strength, fracture toughness, and low cycle fatigue behaviour of 17-4 PH stainless steel, Metallurgical Transactions, 5(7), 1994, pp. 1595-1605.

[4] Clemente R., Lepp N. W., Tungsten. In Heavy Metals in Soils, Springer Netherlands, 2013, pp. 559-564.

[5] Ma D., Xie J., Li J., Liu S., Wang F., Zhang H., Wang W., Wang A., Sun H., Synthesis and hydrogen reduction of nano-sized copper tungsten powders produced by a hydrothermal method, International Journal of Refractory Metals and Hard Materials, 46, 2004 , pp. 152-158. [6] Batchelor J. D., Olcott E. L., Failure mechanics in dense tungsten alloy rocket nozzles, Journal of Spacecraft and Rockets, 1(6), 1964, pp. 635-642.

[7] Park D. Y., Oh Y. J., Kwon Y. S., Lim S. T., Park S. J., Development of non-eroding rocket nozzle throat for ultra-high temperature environment, International Journal of Refractory Metals and Hard Materials, 42, 2014, pp. 205-214.

[8] Mahamood R. M., Laser Metal Deposition Process of Metals, Alloys, and Composite Materials, Springer, Switzerland, 2018.

[9] Shabat D., Rosenthal Y., Ashkenazi D., Stern A., Mechanical and Structural Characteristics of Fused Deposition Modelling ABS Material, Annals of "Dunarea de Jos" University, Fascicle XII, Welding Equipment and Technology, 28, 2017, pp. 16-24.

[10] Rosenthal I., Sharon Y., Stern A., Multi-Material Processing: Hybrid Disk-Shaped Parts Wrought AA6061 \& AM-SLM AlSi10Mg. Annals of "Dunarea de Jos" University, Fascicle XII, Welding Equipment and Technology, 28, 2017, pp. 5-10.

[11] Berger A., Sharon Y., Ashkenazi D., Stern A., Test artifact for additive manufacturing technology: FDM and SLM preliminary results, The Annals of "Dunarea De Jos" University of Galati Fascicle XII, Welding Equipment and Technology 27, 2016 , pp. 29-37.

[12] Rosenthal I., Stern A., Heat Treatment Investigation of the AlSi10Mg Alloy Produced by Selective Laser Melting (SLM): Microstructure and Hardness, The Annals of "Dunarea De Jos" University of Galati Fascicle XII, Welding Equipment and Technology 27, 2016, pp. 7-11.

[13] Adeyemi A. A., Akinlabi E. T., Mahamood R. M., Influence of Laser power on Microhardness and Wear Resistance Properties of Laser Metal Deposited 17-4 PH Stainless Steel, Annals of "Dunarea de Jos" University of Galati, Fascicle XII, Welding Equipment and Technology. 2018, Accepted.

Annals of "Dunarea de Jos" University, Fascicle XII ISSN 1221-4639

Welding Equipment and Technology, Vol. 29 (Year XXIX)

(C) Galati University Press, 2018

Full paper: pp. 41-46 
[14] Gu D. D., Meiners W., Wissenbach K., Poprawe R., Laser additive manufacturing of metallic components: materials, processes and mechanisms, International Materials Reviews, vol. 57(3), 2012, pp.133-164.

[15] Wang Z., Palmer T. A., Beese A. M., Effect of processing parameters on microstructure and tensile properties of austenitic stainless steel 304L made by directed energy deposition additive manufacturing, Acta Materialia, vol. 110, 2016, pp. 226 - 235.

[16] Mahamood R. M., Akinlabi E. T., Shukla M., Pityana S., Effect of processing parameters on properties of laser metal deposited Ti6Al4V using design of experiment, IAENG Transactions on Engineering Sciences, Taylor \& Francis Group, London, ISBN 978-1-138-001367, 2014, pp. 331-339

[17] Bayode A., Akinlabi E. T., Pityana S., Characterization of Laser Metal deposited 316L Stainless Steel, Proceedings of the World Congress on Engineering, vol. 2, ISSN: 2078-0958 (Print); ISSN: 2078-0966 (Online), 2016.

[18] Bayode A., Akinlabi E. T., Pityana S., Microstructure and Microhardness of 17-4 PH Stainless Steel Made by Laser Metal Deposition. Proceedings of the World Congress on Engineering, vol. II, ISBN: 978-988-14048-2-4, 2016.

[19] Adeyemi A. A., Akinlabi E. T., Mahamood R. M., Sanusi K. O., Pityana S., Tlotleng, M., Influence of laser power on microstructure of laser metal deposited 17-4 PH stainless steel, IOP Conference Series: Materials Science and Engineering, vol. 225, no. 1, 2017 , pp. 012028.

[20] Pityana S., Mahamood R. M., Akinlabi E. T., Shukla M., Effect of gas Flow Rate and powder flow rate on Properties of Laser Metal Deposited Ti6Al4V, 2013 International Multi-conference of Engineering and Computer Science (IMECS 2013), 2013, pp. 848-851.

[21] Shukla M., Mahamood R. M., Akinlabi E. T., Pityana S., Effect of Laser Power and Powder Flow Rate on Properties of Laser Metal Deposited Ti6Al4V, World Academy of Science and Technology, vol.6, 2012, 44-48.

[22] Mahamood R. M., Akinlabi E. T., Shukla M., Pityana S., Scanning velocity influence on microstructure, microhardness and wear resistance performance of laser deposited Ti6Al4V/TiC composite, Materials and Design, vol. 50, 2013, pp. 656-666.

[23] Mahamood R. M., Akinlabi E. T., Shukla M., Pityana S., Characterization of Laser Deposited Ti6A14V/TiC Composite Powders on a Ti6A14V Substrate, Lasers in Engineering, vol. 29, 2014, pp. 197-213.

[24] Popoola A. P., Pityana S., Ogunmuyiwa E., Microstructure and wear behaviour of Al/TiB2 metal matrix composite, Advanced Materials Research, 2011, pp. 23-26.

[25] Mahamood R.M., Akinlabi E.T., Effect of Processing Parameters on Wear Resistance Property of Laser Material Deposited Titanium - Alloy Composite, Journal of Optoelectronics and Advanced Materials (JOAM), Vol. 17, No. 9-10, 2015, pp. 1348 - 1360.

[26] Bhadeshia H., Honeycombe R. Steels: Microstructure and Properties, Butterworth-Heinemann, 2011.

[27] Maranian P., Reducing Brittle and Fatigue Failures in Steel Structures, American Society of Civil Engineers, ISBN 978-0-7844-1067$7,2009$.

[28] Duhaj P., Ivan J., Makovicky E., Sigma phase precipitation in austenitic steels, The Journal of the Iron and Steel Institute, vol. 206, 1968 , pp. 1245-1252.

[29] Souza C. M., Abreu H. F. G., Tavares S. S. M., Rebello J. M. A., The $\sigma$ phase formation in annealed UNS S31803 duplex stainless steel: texture aspects, Materials Characterization, vol. 59, no. 9, 2008, pp. 1301-1306. 